ISSN (Online) 2722-1083,

VOL 3 NO 1 OKTOBER 2020

\title{
PENYULUHAN DAN PEMERIKSAAN KESEHATAN (TENSI DARAH, Hb, KOLESTEROL, GULA DARAH, ASAM URAT ) DI DESA TELAGA SARI TANJUNG MORAWA
}

Suryani M.F. Situmeang, Dewi Setiyawati, Suparni

\author{
1,2 ,3,Poltekkes Kemenkes Medan, Jurusan Analis Kesehatan Jalan Willem Iskandar Pasar V Barat Nomor 6 \\ Medan Estate, Indonesia
}

\begin{abstract}
ABSTRAK
Salah satu wujud kepedulian Perguruan Tinggi terhadap lingkungan sosial dan budaya masyarakat (Tri Dharma Perguruan Tinggi) adalah Pengabdian masyarakat. Dengan terjalinnya hubungan yang serasi antara Perguruan Tinggi dengan masyarakat, maka diharapkan adanya masukan untuk perbaikan mutu Perguruan Tinggi dimata masyarakat yang memerlukannya. Telah dilaksanakan Kegiatan Pengabdian Masyarakat Penyuluhan Kesehatan Pemeriksaan Kesehatan Tekanan Darah, Haemoglobin, Kadar gula darah, Kadar Asam urat dan Kadar Kolesterol di Desa Telaga Sari Tanjung Morawa Pada Hari Jumat tanggal 2 Oktober 2020. Sebelum dilakukan penyuluhan, pengetahuan masyarakat mengenai penyakit hipertensi, diabetes, asam urat, kolesterol dan anemia masi sangat rendah. Setelah dilakukan penyuluhan, dilakukan kembali evaluasi berupa post tes pada orang yang sama sebanyak 20 orang, didapatkan semua masyarakat sudah meningkat pengetahuannya. Pemeriksaan Kesehatan bagi masarakat Desa Telaga Sari Kecamatan Tanjung Morawa Kabupaten Deli Serdang berjumlah 103 Orang yang terdiri dari 20 orang Laki- laki dan 83 orang perempuan dimana usia yang di atas 40 tahun berjumlah 74 orang, yang tekanan darahnya meninggi berjumlah 44 orang $(49,7 \%)$, kadar $\mathrm{Hb}$ yang di bawah normal berjumlah 18 orang $(17,47 \%)$ Kadar gula darah yang meninggi 32 orang $(31,6 \%)$, Kadar asam Urat yang meninggi berjumlah 15 orang $(14,6 \%)$ dan 53 orang $(51,45 \%)$ yang kadar kolesterolnya yang meninggi.
\end{abstract}

Kata kunci : Tekanan darah, hemoglobin, Gula Darah, Asam Urat, Kolesterol 
ISSN (Online) 2722-1083,

VOL 3 No 1 OKTOBER 2020

\section{BAB I \\ PENDAHULUAN}

Pemerintah telah melakukan berbagai upaya untuk mencapai visi kementrian kesehatan menuju "Masyarakat Sehat yang Mandiri dan Berkeadilan" melalui berbagai macam kebijakan. Poltekkes Kemenkes Medan turut berpartisipasi dalam berbagai program pemerintah di bidang kesehatan, untuk itu dosen Poltekes Kemenkes Medan dalam melaksanakan Tri Darma Perguruan Tinggi melakukan kegiatan memberikan penyuluhan dan pemeriksaan kesehatan kepada masyarakat.

Desa Telaga Sari merupakan salah satu kelurahan yang ada di Kecamatan Tanjung Morawa, Kabupaten Deli Serdang, Provinsi Sumatra Utara, dengan luas wilayah 200 $\mathrm{ha}^{2}$. Jumlah penduduk sebanyak 1871 kepala keluarga, mata pencaharian penduduk desa Telaga Sari adalah sebagai petani dan sebagian besar buruh di pabrik industri yang ada disekitar wilayah Tanjung Morawa.

Rutinitas pekerjaan sehari-hari menyebabkan masyarakat tidak memperhatikan kesehatan dan sulit minta ijin ke pimpinan tempat bekerja untuk melakukan pemeriksaan ke pusat kesehatan masyarakat. Dengan demikian penyakit yang muncul seakan akan datang mendadak, padahal penyakit generatif sudah dapat terdeteksi secara dini seiring dengan berlanjutnya usia masyarakat produktif. Kenaikan tekanan darah disebut hipertensi yang dapat diukur dengan alat. Penyakit hipertensi menimbulkan kecacatan permanen, kematian mendadak dan yang berakibat sangat fatal. Untuk meningkatkan kualitas hidup agar tidak menimbulkan masalah di masyarakat perlu upaya pencegahan dan penanggulangan hipertensi dimulai dengan meningkatkankesadaran masyarakat dan perubahan pola hidup ke arahyang lebih sehat (Yundini, 2006).

Prevalensi anemia di Indonesia masih cukup tinggi (Fakhidah \& Putri, 2016). Kemenkes RI (2013) menunjukkan angka prevalensi anemia secara nasional pada semua kelompok umur adalah $21,70 \%$. Prevalensi anemia pada perempuan relatif lebih tinggi $(23,90 \%)$ dibanding laki-laki $(18,40 \%)$. Diabetes Mellitus (DM) merupakan salah satu jenis penyakit degeneratif tidak menular yang menjadi masalah serius bagi kesehatan masyarakat di Indonesia maupun di dunia (Krisnatuti \& Yehrina, 2008). Hiperkolesterol ialah keadaan dimana kadar kolesterol dalam tubuh melebihi keadaan normal Hiperkolesterol dapat meningkatkan risiko terkena aterosklerosis, penyakit jantung koroner, pankreatitis (peradangan pada organ pankreas), diabetes melitus, gangguan tiroid, penyakit hepar \& penyakit ginjal. Penyakit asam urat atau dalam dunia medis disebut penyakit pirai atau penyakit gout (arthritis gout) adalah penyakit sendi yang disebabkan oleh tingginya asam urat di dalam darah. Kadar asam urat yang tinggi di dalam darah melebihi batas normal menyebabkan penumpukan asam urat di dalam persendian dan organ tubuh lainnya. Penumpukan asam urat inilah yang membuat sendi sakit, nyeri, dan meradang (Sutanto, 2013).

\section{TINJAUANTEORI}

\section{Darah}

Darah adalah jaringan yang sangat penting di dalam tubuh makhluk hidup karena ia memegang peranan yang sangat vital, yaitu sebagai media transpor nutrisi dan oksigen kepada semua jaringan tubuh agar dapat melakukan metabolisme.

Pada manusia atau mamalia, volume darahnya sekitar 8\% dari berat badannya. Contoh seseorang yang berat badannya $50 \mathrm{~kg}$, berat darahnya lebih kurang $0,08 \times 50 \mathrm{~kg}$ liter darah. Kira-kira volume darah dalam tubuh yang mempunyai massa $50 \mathrm{~kg}$ adalah 4 liter.( Atlas Hematologi, 2015)

\section{Kadar Gula Darah}

Gula darah adalah bahan bakar tubuh yang dibutuhkan untuk kerja otak, sistem saraf, dan jaringan tubuh yang lain. Gula darah yang terdapat di dalam tubuh dihasilkan oleh makanan yang mengandung karbohidrat, protein, dan lemak. Jika gula darah Anda tinggi, itu berarti ada gangguan pada fungsi pankreas untuk menghasilkan insulin. Selain itu ada beberapa faktor lain yang dapat menyebabkan meningkatnya kadar gula darah antara lain, asupan gula yang berlebihan, stres yang berlebihan dan kurangnya olah raga.

Kadar gula (glukosa) normal pada manusia berkisar antara $70-110 \mathrm{mg} / \mathrm{dl}$ setelah berpuasa selama 8 jam. Dua jam setelah makan kadar gliukosa seharusnya di bawah 200 mg/dl. (Gusnaini,D, 2013)

\section{Asam Urat}

Asam urat dalam bahasa inggirs disebut Gout atau penyakit pirai. Gout atau pirai yaitu peradangan yang banyak dirasakan pada persendian otot atau urat dalam tubuh. Namun masyarakat luas lebih mengenalnya dengan penyakit asam urat. Penyakit asam urat sangat erat kaitan dengan ditandai meningkatnya kadar asam urat dalam darah. Penyakit asam urat ini lebih banyak dialami oleh kaum pria dibanding wanita, karena dalam hal ini wanita memiliki kandungan hormon esterogen yang sangat tinggi yang berfungsi sebagai salah satu hormon yang membantu pembuangan kadar asam urat yang terlampau tinggi melalui pembuangan air seni.(Pitasari,D,2014) 
ISSN (Online) 2722-1083, VOL 3 NO 1 OKTOBER 2020

\section{Kolesterol}

Kolesterol adalah alkohol steroid yang ditemukan dalam lemak hewani/minyak, empedu, susu, kuning telur. Kolesterol sebagian besar disintesiskan oleh hati dan sebagian kecil diserap dari diet. Keberadaan kolesterol dalam pembuluh darah yang kadarnya tinggi akan membuat endapan/kristal lempengan yang akan mempersempit/menyumbat pembuluh darah.

Kadar kolesterol didalam darah adalah dibawah $200 \mathrm{mg} / \mathrm{dl}$. Apabila melampaui batas normal maka disebut sebagai hiperkolesterolemia. Hiperkolesterolemia biasanya terdapat pada penderita obesitas, diabetes mellitus, hipertensi, perokok serta orang yang sering minum-minuman beralkohol.

Kolesterol merupakan komponen penting untuk pembentukan membran sel dan disintesis di seluruh jaringan, tetapi $90 \%$ disintesis dalam sel mukosa usus dan hepatosit. Dalam hati kolesterol merupakan precursor dari asam empedu, dalam gonad dan kelenjar, anak ginjal sebagai precursor dari hormon steroid. Asam lemak bebas ( free fatty acids) dibebaskan ke dalam plasma oleh lemak jaringan, diantara waktu-waktu makan dan selama berpuasa digunakan sebagai bahan bakar terutama oleh jaringan otot dan jantung.

\section{METODE}

Pengabdian kepada masyarakat yang dilaksanakan yaitu :

1. Penjajakan :

- Lokasi Pengabdian

- Jumlah Peserta

- Sumber informasi : Kepala Desa Telaga Sari

- Dukungan tempat, lokasi dan izin pelaksanaan

2. Pelaksanaan

Mekanisme pelaksanaan pengabdian masyarakat :

1. Memberikan masker, memberikan hand sanitizer kepada masyarakat

2. Mengukur suhu tubuh masyarakat

3. Membagi kuesioner kepada masyarakat (pre-test)

4. Melakukan penyuluhan kepada masyarakat

5. Melakukan pemeriksaan tekanan darah, $\mathrm{Hb}$, Gula darah, asam urat, kolesterol

Pendaftaran Pelaksanaan Kegiatan Pemeriksaan Gula Darah, asam urat, kolesterol

Pada kegiatan ini dilakukan pemeriksaan tekanan darah menggunakan alat spignomanometer, kadar $\mathrm{HB}$, gula, asam urat, dan kolesteol darah menggunakan alat ukur GCU-meter dengan mengambil darah perifer di ujung jari sebagai sampel pemeriksaannya. Setelah diperiksa, peserta dipersilakan untuk berkonsultasi dengan dokter yang bertugas sesuai dengan keluhan dan masalah kesehatan yang dialami.

\section{PELAKSANAAN KEGIATAN}

Pelaksanaan kegiatan pengabdian kepada masyarakat pada tanggal 2 Oktober 2020 dan tempat pengabdian adalah di Balai Desa Telaga Sari Tanjung Morawa. Penyuluhan disampaikan kepada masyarakat dengan metode ceramah. Sampel berupa darah responden yang berjumlah 103 orang, masing-masing diambil darah kapiler beberapa tetes sesuai kebutuhan pemeriksaan. Kegiatan pemeriksaan kesehatan ini menggunakan alat lancet, alkohol, swab alkohol, GCU meter.

Pelaksanaan kegiatan ini melibatkan mahasiswa Poltekkes Kemenkes Medan berjumlah 5 orang yang langsung ikut melakukan pemeriksaan kesehatan kepada masyarakat.

Sebelum penyuluhan diberikan pre test kepada 20 orang responden dan setelah penyuluhan dan pemeriksaan dilakukan lagi post test kepada 20 orang responden.

\section{HASIL}

\section{Hasil Penyuluhan Kesehatan}

Pengetahuan masyarakat mengenai pengetahuan sebelum penyuluhan menunjukkan dari 20 orang masyarakat tidak mengetahui kadar gula darah, asam urat dan kolesterol dan 10 dan hanya 10 orang yang menyatakan pentingnya melakukan pemeriksaan kesehatan. Dan tidak ada mengetahui gejala dan pencegahan penyakit generatif tersebut.

Setelah dilakukan penyuluhan kesehatan kepada masyarakat desa Telaga Sari dilakukan post tes dengan membagikan kuesioner yang sama dan semua masyarakat (20 orang) sudah mengetahui tekanan darah, kadar hemoglobin, kadar gula darah, kolesterol dan asam urat diri masing-masing, Mengetahui pentingnya melakukan pemeriksaan kesehatan, mengetahui gejala sakit diabetes, asam urat, mengetahui gejala hipertensi, mengetahui penyakit kolesterol, mengetahui pencegahan penyakit diabetes, asamurat, kolesterol dan hipertensi. 
ISSN (Online) 2722-1083,

VOL 3 NO 1 OKTOBER 2020

2. Gambaran Hasil Pemeriksaan Tekanan Darah Masyarakat

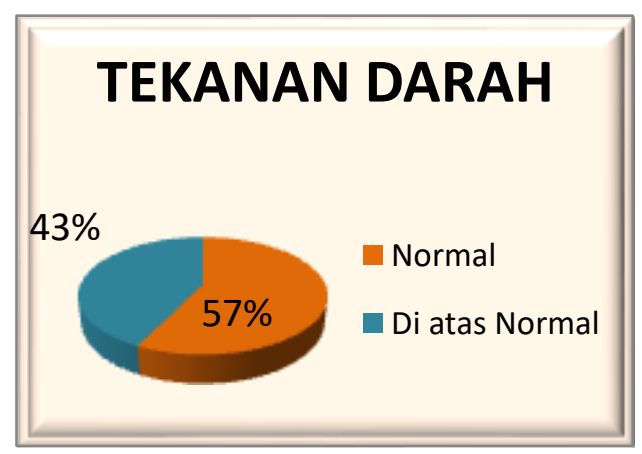

5. Gambaran Hasil Pemeriksaan Asam Urat

3. Gambaran Hasil Pemeriksaan Haemoglobin
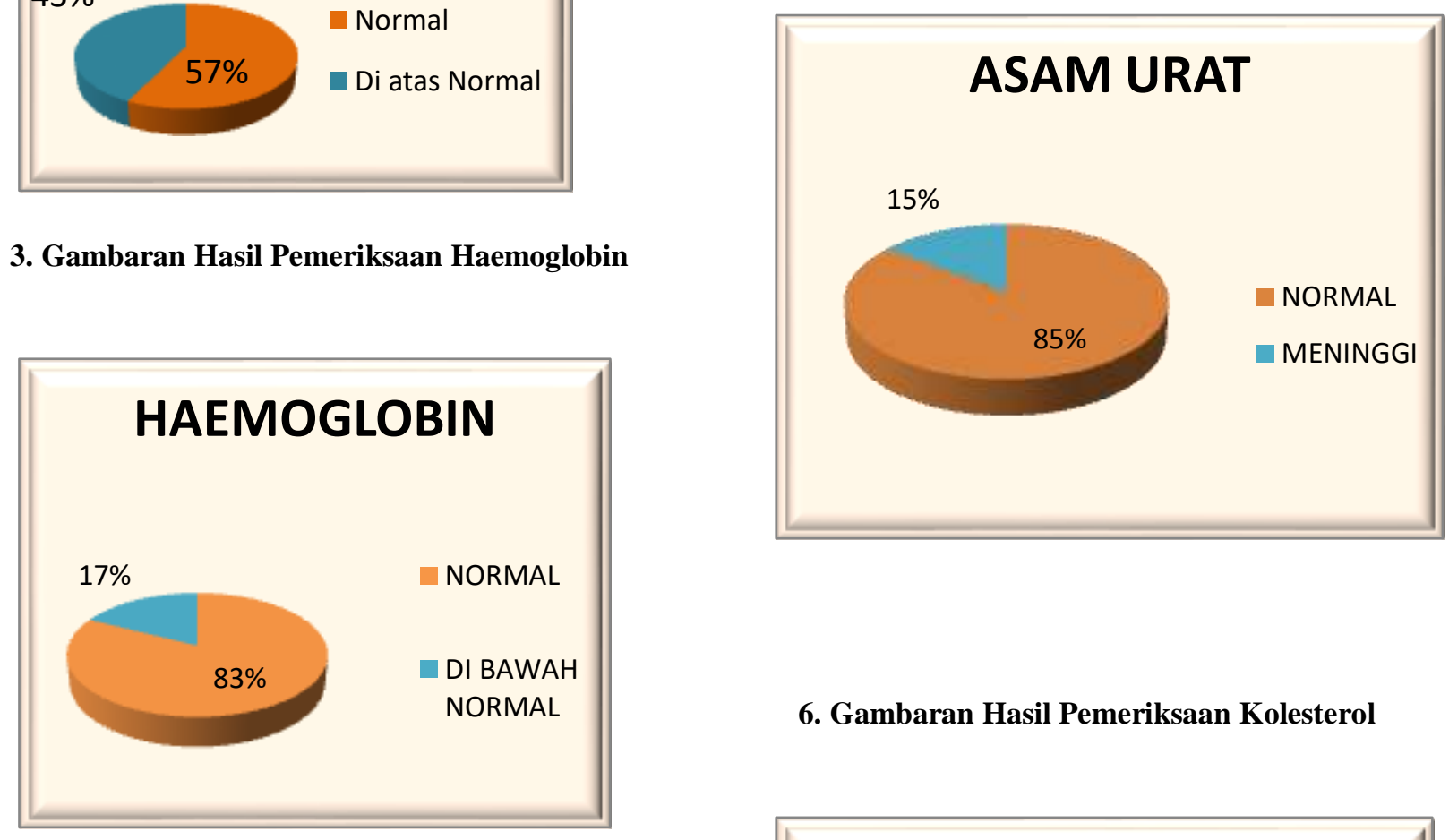

4. Gambaran Hasil Pemeriksaan Kadar Gula Darah

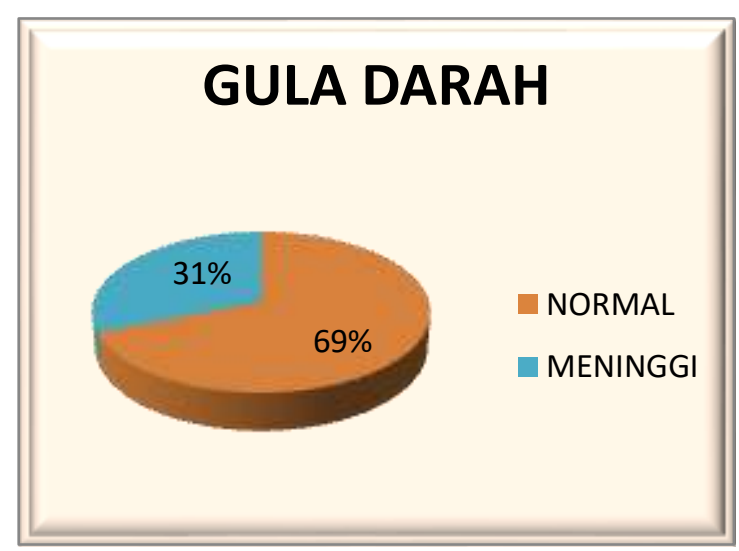


ISSN (Online) 2722-1083,

VOL 3 NO 1 OKTOBER 2020

DAFTAR PUSTAKA

Baron. 1991. Kapita Selekta Patologi Klinik. Buku

EGC:

Kedokteran Jakarta Hoffbrand, 2011.Kapita

Selekta

Hematologi.Buku Kedokteran EGC: Jakarta

I Made Bakta. 2003. Hematologi Klinik Ringkas. Buku Kedokteran EGC: Jakarta

Inge Sutanto dkk.2013, Parasitologi Kedokteran.

Badan Penerbit Fakultas Kedokteran

Universitas Indonesia : Jakarta

Mohammad Sadikin. 2001. Biokimia Darah. Widya Medika: Jakarta

Mandell, B. F. Cleveland Clinic Journal of Medicine: Clinical Manifestasions of Hyperuricemia and Gout, Department of Rheumatic and Immunologic Diseases, Center for Vasculitis Care and Research, Cleveland Clinic, Cleveland, 2008.

Murray, D.V. Metabolisme Lipid: Pengangkutan \& Penyimpanan Lipid. dalam: Kathleen M.Bootham \& Peter A. Mayes. Biokimia Haper. Edisi 27. Jakarta: EGC;

Nurhidayah, Astuti R, and Nurrahman. Black Rice Potential in HDL and LDL Profile in Sprague Dawlay Rat withHigh Cholerterol Diet. IOP Conference Series. Earth and Environmental Science, 2019.

Price Sylvia A, Lorraine M. Wilson. Patofisiologi Konsep Klinis ProsesProses Penyakit, edisi 6. Jakarta : Penerbit Buku Kedokteran EGC, 2006.

Rochmah, W. Buku Ajar Ilmu Penyakit Dalam: Diabetes Mellitus pada Usia Lanjut, Edisi Keempat, Pusat Penerbitan IPD FKUI, Jakarta, 2007.

Ronco C., Franscesco R. Hyperuricemic Syndromes: Pathophysiology and Therapy Vo. 147, Karger, New York, 2005.

Sri Hidajati B.S. dkk. 2009. Atlas Parasitologi Kedokteran. Buku Kedokteran EGC: Jakarta 